

\section{PEMBERDAYAAN MASYARAKAT: PENINGKATAN KAPABILITAS PENGURUS KOPERASI MELALUI PELATIHAN ADMINISTRASI KEUANGAN DI KOPERASI AISYIYAH PDA SE WILAYAH KOTA BENGKULU}

\author{
Suharmi $^{1}$, Ummul Khair ${ }^{2}$, Diah Khairiyah ${ }^{3}$ \\ Universitas Muhammadiyah Bengkulu
}

\begin{abstract}
ABSTRAK
Permasalahan yang dihadapi oleh pengurus koperasi Aisyiyah adalah kurangnya pengetahuan mengenai administrasi koperasi dan laporan keuangan. Hal ini dikarenakan kurangnya pelatihan, karena koperasi Aisyiyah tersebar di kabupaten maka jarang sekali mendapatkan pelatihan. Pelatihan jarang sekali bahkan hampir tidak pernah diadakan di kabupaten. Pelatihan sering diadakan di Kota saja, pengurus koperasi merasa kesulitan untuk mengikuti pelatihan karena jarak tempuh yang cukup jauh sehingga memerlukan waktu dan biaya yang tidak sedikit.

Metode pelaksanaan yang dipilih oleh pengabdi adalah penyuluhan dan pelatihan. Penyuluhan dilaksanakan agar pengurus koperasi paham mengenai administrasi koperasi. Kemudian pelatihan dilaksanakan agar pengurus koperasi memiliki pengetahuan mengenai membuat laporan keuangan sesuai dengan standar akuntansi koperasi yang berlaku umum.

Dampak dari pengabdian ini adalah terjadi peningkatan pengetahuan dan keterampilan pemahaman mengenai administrasi koperasi dan pembuatan laporan keuangan. Pemahaman pengurus koperasi mengenai administrasi koperasi mengalami peningkatan dari $25 \%$ menjadi $70 \%$, hal ini menunjukkan ada peningkatan sebesar $45 \%$. Pemahaman pengurus koperasi Aisyiyah mengenai laporan keuangan juga mengalami peningkatan dari $10 \%$ menjadi 50\%, peningkatan terjadi sebesar $40 \%$.
\end{abstract}

Kata Kunci: Koperasi Aisyiyah, Administrasi Koperasi, Laporan Keuangan

\section{Pendahuluan}

Koperasi Aisyiyah berdiri sejak tahun 2002. Pada awal berdirinya koperasi Aisyiyah memiliki anggota sebanyak 30 orang. Koperasi Aisyiyah berbadan hukum pada tahun 2008. Pada tahun 2019, jumlah anggota koperasi Aisyiyah meningkat menjadi 143 orang. Koperasi Aisyiyah tidak hanya ada di Kota Bengkulu, namun tersebar di 9 Kabupaten yang ada di Bengkulu, yaitu Bengkulu Tengah, Seluma, Kepahyang, Rejang Lebong, Lebong, Bengkulu Selatan, Kaur, MukoMuko, dan Bengkulu Utara.

Pengurus koperasi Aisyiyah saat ini belum memahami mengenai administrasi koperasi serta mengalami kesulitan dalam melakukan pembukuan transaksi yang terjadi pada koperasi, karena pengetahuan dan pemahaman yang masih kurang mengenai pembukuan.Selama ini, pembukuan yang dilakukan masih secara sederhana dan manual. Hal ini menyebabkan laporan keuangan yang dibuat oleh pengurus koperasi belum begitu akurat.Laporan keuangan merupakan salah satu laporan yang harus disusun oleh pengurus koperasi sebagai bentuk peratanggung jawaban terhadap pengelolaan dana kepada anggota selaku pemilik koperasi (Hetika dkk, 2018).

Pengurus koperasi harus menyajikan laporan keuangan yang menggambarkan keadaan yang wajar, karena laporan keuangan sangat penting sebagai bentuk pertanggung jawaban serta memberikan informasi yang penting bagi 


\section{Oivinals}

para anggota untuk menilai koperasi serta untuk menarik anggota baru.Laporan keuangan pada koperasi terdiri laporan sisa hasil usaha (SHU), neraca dan arus kas.

Berdasarkan survey awal yang telah dilakukan, dapat diketahui bahwa pemahaman pengurus koperasi Aisyiyah mengenai pembukuan masih rendah.Hal ini dapat dilihat pada tabel di bawah ini.

\section{Tabel 1}

Persentase Pemahaman Pembukuan Keuangan

\begin{tabular}{|l|c|c|c|c|}
\hline \multicolumn{1}{|c|}{ Keterangan } & Paham & $\begin{array}{c}\text { Kurang } \\
\text { paham }\end{array}$ & $\begin{array}{c}\text { Tidak } \\
\text { Paham }\end{array}$ & Total \\
\hline $\begin{array}{l}\text { Pemahaman } \\
\text { Administrasi } \\
\text { Koperasi }\end{array}$ & $25 \%$ & $40 \%$ & $35 \%$ & $\begin{array}{c}100 \\
\%\end{array}$ \\
\hline $\begin{array}{l}\text { Pemahaman } \\
\text { Laporan } \\
\text { Keuangan }\end{array}$ & $10 \%$ & $35 \%$ & $55 \%$ & $\begin{array}{c}100 \\
\%\end{array}$ \\
\hline
\end{tabular}

Berdasarkan tabel 1 di atas, maka dapat dilihat bahwa banyak sekali pengurus koperasi Aisyiyah yang belum paham mengenai administrasi koperasi.Hal tersebut dapat dibuktikan dari presentase pemahaman mengenai administrasi koperasi. Pengurus koperasi Aisyiyah yang tidak paham sebanyak $35 \%$, kurang paham sebanyak $40 \%$ dan pengurus koperasi yang paham hanya $25 \%$ saja.Kemudian, pengurus koperasi yang paham mengenai laporan keuangan juga sangat sedikit, bisa dikatakan bahwa hampir seluruh pengurus koperasi masih kurang paham, bahkan sangat kurang paham mengenai laporan keuangan.Hal ini dibuktikan oleh presentase pada hasil survey awal. Pengurus koperasi yang paham mengenai laporan keuangan hanya $10 \%$, kurang paham $35 \%$ dan pengurus koperasi yang tidak paham mengenai laporan keuangan adalah $55 \%$.

Setelah melakukan diskusi dengan seluruh pengurus koperasi Aisyiyah, maka kegiatan pelatihan administrasi koperasi bagi pengurus koperasi Aisyiyah akan dilaksanakan. Dengan dilaksanakannya kegiatan ini, maka diharapkan pengurus koperasi dapat menyusun laporan keuangan koperasi. Kegiatan pengabdian masyarakat ini diharapkan dapat bermanfaat sehingga kemampuan kepada pengurus koperasi untuk menyusun laporan keuangan akan meningkat, sehingga pengurus mampu mewujudkan tata kelola koperasi yang transparan dan dapat dipertanggungjawabkan.

\section{Permasalahan Mitra}

Mitra pada pengabdian ini adalah pengurus Koperasi Aisyiyah PDA se wilayah Bengkulu. Permasalahan yang dihadapi oleh pengurus Koperasi Aisyiyah adalah kurangnya pengetahuan mengenai administrasi koperasi dan laporan keuangan. Hal ini dikarenakan pengurus kurang mendapatkan pelatihan.

Lokasi koperasi Aisyiyah menjadi salah satu penyebab jarangnya pengurus mendapatkan pelatihan. Lokasi koperasi Aisyiyah tersebar di beberapa Kabupaten, pelatihan masih jarang dilaksanakan di Kabupaten dan pelatihan lebih sering diadakan di Kota. Pengurus koperasi merasa kesulitan untuk mengikuti pelatihan yang diadakan di Kota karena jarak tempuh yang cukup jauh sehingga memerlukan waktu dan biaya yang tidak sedikit.

Permasalahan selanjutnya adalah pengurus Koperasi Aisyiyah rata-rata tidak memiliki latar belakang pendidikan Akuntansi, hal ini jugalah yang menjadi penyebab utama sulitnya pengurus untuk memahami mengenai administrasi koperasi dan cara pembuatan laporan keuangan.

\section{Solusi Permasalahan}

Berdasarkan permasalahan di atas, maka solusi permasalahannya adalah melakukan penyuluhan mengenai administrasi koperasi. Administrasi koperasi yang dimaksud adalah peyuluhan mengenai administrasi koperasi yang baik, apa saja tugas pengurus koperasi, serta apa saja laporan yang harus disiapkan oleh pengurus koperasi. Kemudian akan 


\section{Ourrater}

dilaksanakan pelatihan mengenai laporan keuangan, pengurus koperasi akan diajarkan apa saja laporan keuangan yang

\begin{tabular}{|c|c|c|c|c|c|c|c|c|c|}
\hline \multirow{2}{*}{$\begin{array}{c}\text { Nama } \\
\text { Kegiatan }\end{array}$} & \multicolumn{9}{|c|}{ Minggu } \\
\hline & 1 & 2 & 3 & 4 & 5 & 6 & 7 & 8 & 9 \\
\hline $\begin{array}{l}\text { Pembuatan } \\
\text { proposal }\end{array}$ & & & & & & & & & \\
\hline $\begin{array}{l}\text { Mengadakan } \\
\text { penyuluhan } \\
: \\
\text { Administrasi } \\
\text { koperasi }\end{array}$ & & & & & & & & & \\
\hline $\begin{array}{l}\text { Mengadakan } \\
\text { pelatihan: } \\
\text { Pembuatan } \\
\text { laporan } \\
\text { keuangan }\end{array}$ & & & & & & & & & \\
\hline Pelaporan & & & & & & & & & \\
\hline
\end{tabular}

harus mereka buat serta mereka akan dilatih bagaimana cara membuat laporan keuangan.

Setelah pelatihan ini dilaksanakan, pengabdi mengharapkan seluruh pengurus koperasi Aisyiyah memiliki pengetahuan mengenai administrasi koperasi serta mampu membuat laporan keuangan berdasarkan aturan yang berlaku, sehingga laporan keuangan mereka dapat dipertanggungjawabkan.

\section{Metode Pelaksanaan}

Metode pelaksanaan yang dipilih oleh pengabdi adalah penyuluhan dan pelatihan.Penyuluhan dilaksanakan agar pengurus koperasi paham mengenai administrasi koperasi.Kemudian pelatihan dilaksanakan agar pengurus koperasi memiliki pengetahuan mengenai membuat laporan keuangan sesuai dengan standar akuntansi koperasi yang berlaku umum.

Pada saat penyuluhan dan pelatihan dilaksanakan, pengabdi memberikan penyuluhan mengenai administrasi koperasi, yaitu mengenai apa pengertian administrasi koperasi, apa saja tugas dan kewajiban, kemudian buku apa saja yang harus dimiliki oleh setiap koperasi. Pengabdi juga memberikan pelatihan mengenai cara pembuatan laporan keuangan. Setelah penyuluhan dan pelatihan ini selesai, pengabdi mengharapkan agar semua pengurus koperasi Aisyiyah paham mengenai administrasi koperasi dan mampu membuat laporan keuangan berdasarakan standar akuntansi koperasi yang berlaku umum.

\section{Jadwal Kegiatan}

\section{Tabel 2.1}

\section{Jadwal Kegiatan}

\section{Gambaran Iptek}

Kegiatan yang dilaksanakan pada pengabdian ini adalah pelatihan.Pelatihan adalah suatu proses yang meliputi tindakan yang dilaksanakan secara sengaja dalam bentuk pemberian bantuan kepada tenaga kerja yang dilakukan oleh tenaga profesional kepelatihan dalam satuan waktu yang bertujuan untuk meningkatkan kemampuan kerja peserta dalam bidang pekerjaan tertentu guna meningkatkan efektivitas dan produktivitas dalam suatu organisasi.

Setelah pelatihan ini dilaksanakan, diharapkan adanya peningkatan pengetahuan dan kemampuan pengurus koperasi Aisyiyah dalam hal administrasi keuangan serta pembuatan laporan keuangan yang sesuai dengan akuntansi koperasi yang berlaku secara umum.

\section{HASIL PENGABDIAN DAN PEMBAHASAN}

Kegiatan pelatihan administrasi keuangan di koperasi Aisyiyah PDA se wilayah kota Bengkulu dilaksanakan pada tanggal 23 - 24 November 2019, kegiatan ini diikuti oleh 30 orang peserta. Pelatihan ini dimulai dengan urutan sebagai berikut:1. Peserta melakukan registrasi, 2. Penyuluhan mengenai administrasi 


\section{Ourrate}

keuangan, 3. Pelatihan mengenai pembuatan laporan keuangan.

Pada sesi pertama hingga sesi terakhir, peserta terlihat sangat antusias, hal ini ditunjukkan dengan keaktifan peserta selama kegiatan berlangsung. Para peserta serius mendengarkan materi yang disampaikan oleh pengabdi dan sangat aktif bertanya. Pada saat pelatihan pembuatan laporan keuangan, para peserta melaksanakan praktek cara pembuatan laporan keuangan. Para peserta sangat semangat dan berusaha semaksimal mungkin untuk membuat laporan keuangan.

\section{Gambar 3.1 Peserta Kegiatan}

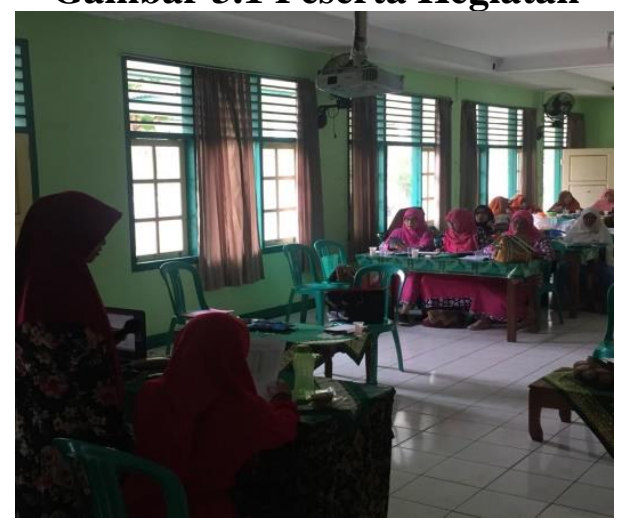

\section{Penyuluhan Administrasi Koperasi}

Kegiatan

pelanyuluhan administrasi koperasi dapat dilihat pada gambar 3.2.Pada gambar ini, pengabdi menyampaikan materi mengenai administrasi koperasi.

\section{Gambar 3.2}

\section{Penyampaian Materi Penyuluhan}

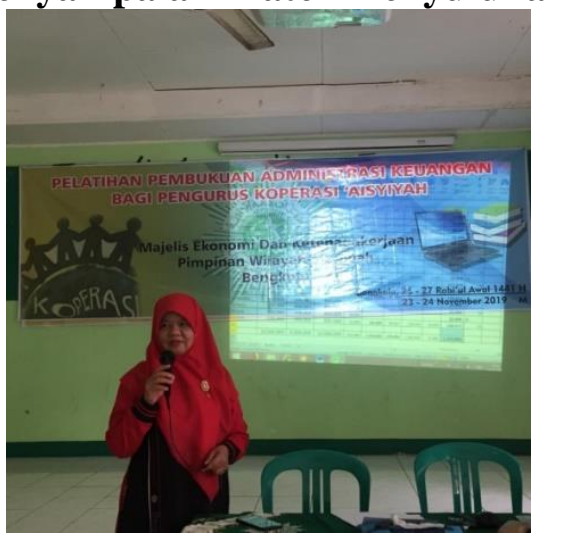

Administrasi dalam arti sempit adalah kegiatan yang meliputi catat mencatat, surat menyurat, pembukuan ringan ketik mengetik, agenda, dan sebagainya yang bersifat teknis ketatausahaan. Sedangkan dalam arti luas, administrasi adalah seluruh proses kerja sama antara dua orang atau lebih dalam mencapai tujuan dengan memanfaatkan sarana dan prasarana tertentu secara berdaya guna dan berhasil guna.

Administrasi organisasi koperasi merupakan suatu system administrasi yang berhubungan dengan aktivitas-aktivitas keanggotaan, kepengurusan, dan pengelolaan koperasi.Dalam menyusun kebijakan-kebijakan oleh pengurus, harus didasarkan atas landasan kerja dan sekaligus dijadikan acuan dalam operasional kegiatan-kegiatan yang dilakukan di Koperasi.Oleh karena itu, administrasi koperasi sangat penting, untuk mengidentifikasi aspek-aspek terkait kebijakan-kebijakan dimaksud, agar operasional kegiaatan-kegiatan berjalan baik dan tidak terlepas dari ketentuan yang ditetapkan.

Pada administrasi koperasi tugas dan kewajiban pengurus koperasi harus jelas.Pengurus koperasi adalah orangorang yang dipilih untuk masa jabatan paling lama lima tahun sesuai dengan anggaran koperasi. Pengurus koperasi bertanggung jawab langsung keada rapat anggota.Tugas dan kewajiban pengurus koperasi adalah memimpin organisasi dan usaha koperasi serta mewakilinya di muka dan di luar pengadilan sesuai dengan keputusan-keputusan rapat anggota.Pengurus koperasi terdiri dari ketua, sekretaris, bendahara, administrasi. Tugas dan kewajiban pengurus koperasi adalah sebagai berikut:

1. Menyelenggarakan dan mengendalikan usaha koperasi

2. Melakukan seluruh perbuatab hokum atas nama koperasi

3. Mewakili koperasi di dalam dan di luar pengadilan 
4. Mengajukan rencana kerjaa, rencana anggaran pendapatan dan belanja koperasi

5. Menyelenggarakan rapat anggota serta mempertanggungjawabkan pelaksanaan

tugas

kepengurusannya

6. Memutuskan penerimaan anggota baru, penolakan anggota serta pemberhentian anggota

7. Membantu pelaksanaan tugas pengawasan dengan memberikan keterangan dan memperlihatkan bukti-bukti yang diperlukan

8. Memberikan penjelasan dan keterangan kepad anggota mengenai jalannya organisasi dari usaha koperasi

9. Memelihara kerukunan diantara anggota dan mencegah segala hal yang menyebabkan perselisihan

10. Menanggung kerugian koperasi sebagai akibat karena kelalaiannya dengan ketentuan yang berlaku

11. Meminta jasa audit kepada koperasi jasa audit dan atau akuntan publik yang biayanya ditanggung oleh koperasi dan biaya audit tersebut dimasukkan dalam anggaran biaya koperasi

12. Menyusun ketentuan mengenai tugas, wewenang dan tanggung jawab anggota pengurus serta ketentuan mengenai pelayanan terhadap anggota

13. Pengurus atau salah seorang yang ditunjuk berdasarkan ketentuan yang berlaku dapat melakukan tindakan hokum yang bersifat pengurusan dan pemilikan dalam batas-batas tertentu berdasarkan persetujuan tertulis dari keputusan rapat pengurus dan pengawas koperasi.

Kegiatan koperasi dapat berjalan dengan baik apabila pengurus memahami mengenai administrasi koperasi, dalam administrasi koperasi ada beberapa buku yang harus dibuat, yaitu: buku daftar anggota, buku daftar pengurus, buku daftar pengawas, buku daftar karyawan, buku tamu, buku simpanan anggota, buku saran anggota, buku anjuran pejabat, buku anjuran pejabat dari instansi lain, buku keputusan rapat pengawas, buku keputusan rapat pengurus, buku keputusan rapat anggota, buku catatan kejadian penting, buku kas, buku catatan inventaris, dan buku agenda. Selain buku-buku tersebut, koperasi juga harus membuat buku pembantu piutan dan buku pembantu hutang.

Pelatihan ini diharapkan dapat memberikan materi dan pengetahuan yang berguna bagi pengurus koperasi, sehingga pengurus koperasi dapat memiliki kemampuan dalam hal administrasi koperasi.Koperasi bisa berjalan dengan baik karena administrasinya baik, pengurus mengetahui dengan jelas tugas dan kewajiban masing-masing.

\section{Pelatihan Pembuatan Laporan \\ Keuangan}

Kegiatan pelatihan pembuatan laporan keuangan dapat dilihat pada gambar 3.3.Pada gambar ini, pengabdi menyampaikan materi mengenai laporan keuangan.

\section{Gambar 3.3}

Penyampaian Materi Pelatihan

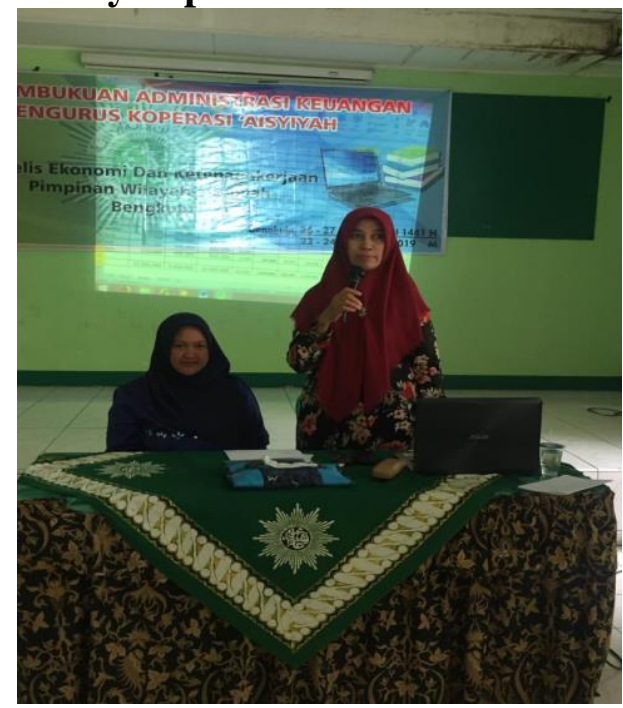




\section{Ourrales}

Laporan keuangan adalah hasil akhir dari proses pencatatan transaksi keuangan perusahaan yang menunjukkan kondisi keuangan perusahaan tersebut pada suatu periode akuntansi serta menunjukkan gambaran umum mengenai kinerja suatu perusahaan.Tujuan laporan keuangan adalah screening, understanding, forecasting, diagnosis, dan evaluation.Pihak yang berkepentingan adalah pemilik/anggota koperasi, manajemen perusahaan/ pengurus koperasi, kreditur, investor, pemerintah dan karyawan.

Laporan keuangan bersifat historis dan menyeluruh, yang terdiri dari data yang merupakan hasil dari kombinasi: Fakta yang telah dicatat, prinsip-prinsip dan kebiasaan di dalam akuntansi, pendapat pribadi. Laporan keuangan yang harus dibuat oleh koperasi adalah laporan sisa hasil usaha (SHU), neraca, dan arus kas.

SHU adalah sejumlah pendapatan koperasi yang diperoleh dalam satu tahun setelah dikurangi dari penyusutan serta beban dari tahun buku yang bersangkutan.Bentuk laporan SHU yaitu, 1. Koperasi simpan pinjam dan jasa: single step, 2. Koperasi konsumen dan produsen: multiple step.

Neraca adalah laporan sistematis tentang aktiva, utang dan modal dari suatu perusahaan pada saat tertentu.Aktiva pada neraca terdiri dari aktiva lancar dan aktiva tidak lancar.Aktiva lancar adalah aktiva yang dapat dijadikan uang dalam jangka pendek, yang termasuk aktiva lancar antara lain adalah kas, investasi jangka pendek, piutang wesel, piutang dagang, persediaan, piutang penghasilan, persekot biaya. Sedangkan aktiva tidak lancar adalah aktiva yang memiliki umur kegunaan relative permanen atau jangka panjang, yang termasuk aktiva tidak lancar adalah investasi jangka panjang, aktiva tetap berwujud, aktiva tetap tidak berwujud, beban yang ditangguhkan, aktiva lain-lain.Utang pada neraca terdiri dari utang jangka pendek dan utang jangka panjang.Yang termasuk utang jangka pendek adalah utang dagang, utang wesel, utang pajak, biaya yang masih harus dibayar, utang jangka panjang yang segera jatuh tempo, sedangkan yang termasuk utang jangka panjang adalah utang obligasi, utang hipotik, dan utang jangka panjang lainnya. Kemudian yang termasuk modal adalah cadangan, modal saham dan laba ditahan.Bentuk neraca adalah scontro (horizontal), staffel (vertical), dan yang disesuaikan dengan posisi keuangan.

Laporan keuangan terakhir yang harus dibuat oleh pengurus koperasi adalaah arus kas (cash flow). Arus kas adalah laporan keuangan yang berisi tentang penerimaan dan pengeluaran kas pada suatu perusahaan pada periode waktu tertentu.

Pelatihan mengenai pembuatan laporan keuangan ini dengan maksud agar para pengurus koperasi mengetahui dengan pasti apa yang dimaksud laporan keuangan. Kemudian apa saja laporan keuangan yang harus dibuat, dan bagaimana cara membuat laporan keuangan. Sehingga posisi keuangan koperasi dapat diketahui dengan jelas oleh anggota koperasi dan kepercayaan anggota akan meningkat.

\section{Pembahasan}

Pengabdian pada pengurus koperasi Aisyiyah berjalan dengan lancar, hanya ada beberapa hambatan yang dirasakan selama pengabdian dilaksanakan, salah satunya adalah sulitnya peserta memahami materi yang disampaikan oleh pengabdi, hal ini menyebabkan pengabdi harus menjelaskan materi berulang kali sampai peserta benarbenar memahami.Berikut ini dapat diketahui faktor-faktor pendukung dan faktor penghambat pengabdian pada masyarakat pada pengurus koperasi Aisyiyah:

1. Faktor Pendukung

a. Pengurus koperasi Aisyiyah 
memiliki keinginan yang kuat untuk meningkatkan pengetahuanmengenai administrasi koperasi dan laporan keuangan.

b. Pimpinan Aisyiyah sangat mendukung penyuluhan administrasi

koperasidanpelatihanpembuatan laporan keuangan.

2. Faktor Penghambat

a. Beberapa peserta terlihat belum paham mengenai cara pembuatan laporan keuangan.

b. Peserta membutuhkan waktu yang cukup lama untuk mencoba membuat laporan keuangan, sehingga waktu yang tersedia kurang.

\section{Dampak}

Dampak dari kegiatan pengabdian ini adalah meningkatnya pengetahuan dan keterampilan pengurus koperasi. Peningkattan pengetahuan dan keterampilan pengurus koperasi ini menunjukkan bahwa pengurus koperasi menganggap penyuluhan dan pelatihan mengenai administrasi koperasi dan laporan keuangan ini sangat penting. Hal ini dapat dilihat pada tabel berikut ini:

Tabel 3.1

Presentase perubahan pemahaman sebelum dan setelah pengabdian

Berdasarkan tabel 3.1 diatas, maka dapat dilihat dengan jelas bahwa terjadi peningkatan pengetahuan dan keterampilan pemahaman mengenai administrasi koperasi dan pembuatan laporan keuangan. Pemahaman pengurus koperasi mengenai administrasi koperasi mengalami peningkatan dari $25 \%$ menjadi $70 \%$, hal ini menunjukkan ada peningkatan sebesar 45\%. Jumlah pengurus koperasi yang kurang paham mengenai administrasi koperasi menurun dari $40 \%$ menjadi $15 \%$, penurunan yang terjadi adalah sebesar 25\%. Kemudian jumlah pengurus koperasi yang tidak paham mengenai administrasi koperasi menurun dari $35 \%$ menjadi $15 \%$, penurunan yang terjadi adalah sebesar $20 \%$.

Pemahaman pengurus koperasi Aisyiyah mengenai laporan keuangan juga mengalami peningkatan. Pada tabel 3.1 dapat dilihat bahwa jumlah pengurus koperasi yang paham tentang laporan keuangan meningkat dari $10 \%$ menjadi $50 \%$, peningkatan terjadi sebesar $40 \%$. Sedangkan jumlah pengurus koperasi yang kurang paham dan tidak paham mengenai laporan keuangan menurun. Jumlah

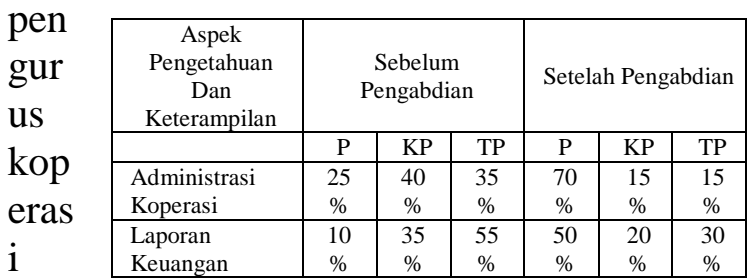

yang kurang paham mengenai laporan keuangan menurun dari $35 \%$ menjadi $20 \%$, hal ini menunjukkan ada penurunan sebesar $15 \%$. Kemudian, jumlah pengurus koperasi yang tidak paham mengenai laporan keuangan menurun dari 55\% menjadi 30\%, hal ini menunjukkan penurunan sebesar $25 \%$.

Peningkatan pemahaman pengurus koperasi Aisyiyah mengenai administrasi koperasi dan kaporan keuangan ini adalah karena mereka semangat dan serius dalam mengikuti penyuluhan dan pelatihan pada kegiatan pengabdian ini. Harapan tim pengabdian adalah para pengurus koperasi dapat menerapkan ilmu yang telah mereka peroleh selama penyuluhan dan pelatihan berlangsung.

\section{Kesimpulan}

Pengabdian pemberdayaan masyarakat: peningkatan kapabilitas pengurus koperasi melalui pelatihan administrasi keuangan di koperasi Aisyiyah PDA se wilayah kota Bengkulu yakni penyuluhan administrasi koperasi 


\section{Ourrales}

dan pelatihan pembuatan laporan keuangan berjalan dengan baik dan lancar sesuai rencana, keberhasilan pelatihan ini ditunjukkan oleh antusias para peserta pelatihan koperasi, para peserta sangat aktif selama kegiatan berlangsung. Setelah pelatihan dilaksanakan ada peningkatan pengetahuan para pengurus koperasi mengenai administrasi koperasi dan laporan keuangan, hal ini dibuktikan dengan presentase pada pemahaman pengurus koperasi Aisyiyah.

\section{DAFTAR PUSTAKA}

Bati, et al. 2019. Pelatihan Akuntansi Bagi Pengurus dan Anggota KSU Pemuda Kisaran. Jurnal Anadara Pengabdian Kepada Masyarakat Vol 1 No 1.

Hetika, Yeni Priatna Sari, Ririh Sri Harjanti. 2018. Upaya Peningkatan Keterampilan Menyusun Laporan Keuangan Bagi Pengurus Koperasi Batik Tegalan Cempaka Mulya. Jurnal Abdimas PHB Vol 1 No 1.

Safelia, Nela, et al. 2015. IbM pada Koperasi di Kota Jambi dalam Rangka Meningkatkan Kualitas Laporan Keuangan Koperasi dengan Pemanfaatan teknologi Sistem Informasi Akuntansi. Jurnal Pengabdian pada MAasyarakat Volume 30 No 3.

\subsection{Saran}

Berdasarkan evaluasi dari kegiatan yang sudah dilakukan,saran yang dapat diberikan adalah sebagai berikut:

1. Kegiatan ini dapat dilanjutkan dengan memberikan materi lanjutan, pada kegiatan selanjutnya diharapkan agar ada penambahan waktu serta penambahan biaya agar pelaksanaan kegiatan lebih maksimal.

2. Perlunya kegiatan lanjutan terkait administrasi koperasi serta pelatihan pembuatan laporan keuangan.

Sasongko, Catur, et al. 2016. Akuntansi Suatu Pengantar-Berbasis PSAK. Jakarta. Salemba Empat.

Tri Maryati. 2017. Pendampingan Administrasi Keuangan "Koperasi Sejahtera" Pertuni Cabang Sleman. Laporan Pengabdian. Universitas Muhammadiyah Yogyakarta.

Undang-Undang Republik Indonesia Nomor 25 Tahun 1992 Tentang Perkoperasian. http://hukum.unsrat.ac.id/uu/uu _25_92.htm. diperoleh pada tanggal 20 November 2019. 